\title{
Effect of proteolysis during Cheddar cheese aging on the detection of milk protein residues by ELISA
}

\author{
Katherine O. Ivens, ${ }^{*}$ Joseph L. Baumert, ${ }^{*}$ Robert L. Hutkins, $†$ and Steve L. Taylor*1 \\ ${ }^{*}$ Food Allergy Research and Resource Program, Department of Food Science and Technology, University of Nebraska-Lincoln, PO Box 886207 , \\ Lincoln 68588 \\ †Department of Food Science and Technology, University of Nebraska-Lincoln, Lincoln 68588
}

\section{ABSTRACT}

Cow milk is a common allergenic food, and cow milkderived cheese retains an appreciable level of allergenicity. The specific and sensitive detection of milk protein residues in foods is needed to protect milk-allergic consumers from exposure to undeclared milk protein residues contained in foods made with milk or milkderived ingredients or made on shared equipment or in shared facilities with milk or milk-derived ingredients. However, during cheese ripening, milk proteins are degraded by chymosin and milk-derived and bacterial proteases. Commercial allergen-detection methods are not validated for the detection of residues in fermented or hydrolyzed products. The objective of this research was to evaluate commercially available milk ELISA kits for their capability to detect milk protein residues in aged Cheddar cheese. Cheddar cheese was manufactured at a local dairy plant and was aged at $5^{\circ} \mathrm{C}$ for $24 \mathrm{mo}$, with samples removed at various time points throughout aging. Milk protein residues and protein profiles were measured using 4 commercial milk ELISA kits and sodium dodecyl sulfate-PAGE. The ELISA data revealed a $90 \%$ loss of milk protein residue signal between the youngest and oldest Cheddar cheese samples ( 0.5 and 24 mo, respectively). Sodium dodecyl sulfate-PAGE analysis showed protein degradation throughout aging, with the highest level of proteolysis observed at 24 mo. Results suggest that current commercial milk ELISA methods can detect milk protein residues in young Cheddar cheese, but the detection signal dramatically decreases during aging. The 4 evaluated ELISA kits were not capable of detecting trace levels of milk protein residues in aged cheese. Reliable detection of allergen residues in fermented food products is critical for upholding allergen-control programs, maintaining product safety, and protecting allergic consumers. Fur-

Received June 21, 2016.

Accepted November 12, 2016.

${ }^{1}$ Corresponding author: staylor2@unl.edu thermore, this research suggests a novel use of ELISA kits to monitor protein degradation as an indication of cheese ripening.

Key words: ELISA, milk, cheese, proteolysis

\section{INTRODUCTION}

Cow milk represents one of the most common allergenic foods around the world (Sampson, 2004). Cow milk contains several major allergenic proteins, including casein, $\beta-\mathrm{LG}$, and $\alpha$-LA (Wal et al., 2001). Milk-allergic individuals are advised to avoid all milkderived food products and ingredients to mitigate the risk of accidental consumption (Sicherer and Sampson, 2010). The level of risk of an allergic reaction is related to the dose of exposure to milk proteins. However, milk-allergic individuals vary widely with respect to their threshold doses for milk proteins (Skripak et al., 2008). Fermented milk products, including cheeses, are assumed to retain their allergenicity, and empirical evidence indicates that milk-allergic individuals can react to ingestion of cheese (Alessandri et al., 2012). The proteolysis that occurs during cheese aging is likely to affect the level and nature of milk allergens especially in aged cheeses. However, only one clinical study has addressed the allergenicity of cheeses, as compared with milk. In that study, approximately $58 \%$ of milk-allergic patients tolerated fully matured Parmigiano-Reggiano cheese (Alessandri et al., 2012). Thus, despite the advice milk-allergic individuals are given to avoid cheeses, the degree of tolerance to various cheeses among milkallergic individuals has not been thoroughly examined.

Proteolysis plays a fundamental role in cheesemaking. Initially, chymosin (or other coagulants) hydrolyzes $\kappa-\mathrm{CN}$ into para-k-CN and glycomacropeptide, destabilizing the milk micelle, thereby causing formation of the cheese matrix and giving cheese its gel-like structure (Fox, 1989). Proteases from the coagulant, starter culture, and other sources also play a significant role in developing characteristic flavors and texture during ripening. Depending on the length and extent of cheese 
ripening, substantial proteolysis can occur. Collectively, proteolytic activity is attributed to chymosin (or rennet), indigenous milk proteases, and the proteases of starter and nonstarter microorganisms.

Proteolysis in cheese is divided into 3 major events: coagulation of curd, primary proteolysis, and secondary proteolysis. Coagulation of the curd as a result of destabilization of the milk micelle and formation of the cheese matrix is initiated by the hydrolytic action of chymosin on $\kappa$-CN. Primary proteolysis is the action of proteolytic enzymes to degrade native caseins into peptide fragments (Grappin et al., 1985). Secondary proteolysis is the continued degradation of peptide fragments into smaller casein-derived peptides and free AA (Rank et al., 1985). Primary proteolysis is largely dominated by the activities of chymosin and the indigenous milk protease plasmin, and to a somewhat lesser extent by lactic acid bacteria. Secondary proteolysis, however, is characterized by the diverse specificities of the peptidases of starter and nonstarter microorganisms.

During cheesemaking, the whey protein fraction and its 2 major allergens, $\alpha-\mathrm{LA}$ and $\beta-\mathrm{LG}$, are removed; thus, the main proteolytic substrates are the various fractions of casein. In general, chymosin hydrolyzes $\alpha_{\mathrm{S1}}$-CN at several sites during the early stages of ripening. In studies of Cheddar cheese ripening, less than $15 \%$ of the original $\alpha_{\mathrm{S}_{1}} \mathrm{CN}$ remained intact after 90 d (Børsting et al., 2012; Møller et al., 2012). Due to its low water activity, $\beta-\mathrm{CN}$ is highly resistant to hydrolysis by chymosin, but about $50 \%$ is degraded during Cheddar cheese ripening after $270 \mathrm{~d}$ (Børsting et al., 2012; Møller et al., 2012). Plasmin, an indigenous milk protease, preferentially hydrolyzes $\beta$-CN during primary proteolysis (Fox et al., 2015). Chymosin has not been documented to degrade para-k-CN during ripening (Hayaloglu and McSweeney, 2014). The fraction of $\kappa$-CN remaining in the cheese after coagulation is largely resistant to proteolysis during the early stages of ripening.

Several extraction and fractionation protocols, based on the liberation of peptide fragments and free AA, have been developed to evaluate the extent of ripening and proteolysis in cheese (Møller et al., 2012; Yu et al., 2012; Karametsi et al., 2014). As aging continues, the number of large peptides isolated from cheese dramatically decreases, and ripening is dominated by the release of small peptides and free AA (Parente et al., 2012; Møller et al., 2013). Larger pH 4.6-soluble peptides are typically derived from the action of chymosin, whereas $\mathrm{pH}$ 4.6-insoluble fragments are typically $\gamma$-CN derived from the action of plasmin on $\beta$-CN (Fox et al., $2015)$. The $\gamma$-CN have been used in several studies as an indicator of ripening, particularly with Parmigiano-
Reggiano and Grana Padano cheeses (Cattaneo et al., 2008; Masotti et al., 2010). The small peptides produced during ripening, especially those produced during secondary proteolysis, are particularly difficult to visualize with electrophoretic methods.

Even though these general features characterize cheese proteolysis, dramatic differences occur in proteolysis during the manufacturing of various types of cheese as a result of myriad environmental factors, including $\mathrm{pH}$, water activity, cook temperature, storage conditions, fat content, and homogenization (Larsen et al., 2010; Deegan and McSweeney, 2013; Di Luccia et al., 2013). Microbial proteases vary widely in their specificity for hydrolyzing milk proteins. In a study of Cheddar cheese ripening, it was found that different Lactococcus strains had different proteolytic patterns (Gutiérrez-Méndez et al., 2010; Steele et al., 2013; Karametsi et al., 2014). Nonstarter microbial proteases additionally have varying patterns of proteolysis (Steele et al., 2013).

Throughout the aging of Cheddar cheese, several epitopes capable of binding $\mathrm{IgE}$ and eliciting an allergic response remain intact on the most abundant caseins, $\alpha_{\mathrm{S1}^{-}}$and $\beta$-CN (Hayaloglu and McSweeney, 2014; Karametsi et al., 2014). However, some allergenic epitopes can lose their immunoreactive potential as a result of proteolysis during cheese manufacture and aging. The comparative allergenic potency of various types of cheeses has not been carefully assessed. However, established scientific knowledge indicates that proteolytic enzymes can destroy or reveal allergenic epitopes on proteins (Yao et al., 2014; Verhoeckx et al., 2015).

Methods to detect potentially allergenic milk residues in foods are well developed, although accurate detection by some methods can be affected by forms of proteolysis, including fermentation. The most common method are ELISA, because ELISA specifically detect proteins from the allergenic source and allergens are proteins. Additionally, commercial ELISA are available in formats such as lateral flow devices that are rapid and sufficiently rugged to use within manufacturing facilities. However, the protein targets of the antisera used in ELISA vary even for specific foods, such as milk. For milk, commercial ELISA exist for the detection of total milk, casein, and $\beta$-LG (Ivens et al., 2016). Mass spectrometry methods continue to be developed for the detection of food allergen residues. Whereas mass spectrometry methods target the detection of specific proteins or peptides, such proteomics methods are available for milk proteins for only a few food matrices (Weber et al., 2006). Recently developed methods provide improved resolution and allow identification of specific milk proteins and peptides (Møller et al., 2012; Parente et al., 2012; Karametsi et al., 2014). The DNAbased methods to detect allergenic residues in foods 
rely on principles of PCR for detection. Although PCR is sensitive and specific, there is disagreement over whether using DNA as a target molecule accurately represents the concentration of allergenic proteins present in a sample (Stephan and Vieths, 2004); furthermore, for milk, much more protein is present than DNA. Overall, ELISA are relied upon most often to detect residues of allergenic foods in food matrices by the food industry because they are specific, sensitive, accurate, and generally easy to use (Alves et al., 2016).

Commercial immunochemical methods are often designed to detect intact proteins from allergenic foods, making fermented or hydrolyzed food products particularly difficult to assess. If peptides resulting from proteolysis that occur during fermentation and hydrolysis are not detected with commercial immunochemical methods, then false-negative analytical results will be obtained. If such peptides are of sufficient size and structure to retain the allergenicity of the intact protein, then such false-negative results could lead to the distribution of food products with potentially hazardous undeclared allergen residues. Current commercial milk ELISA methods are not validated for the detection or accurate quantification of allergen residues in foods subjected to proteolysis. The relationship between the extent of proteolysis and the detection of milk proteins using commercial ELISA kits has not been evaluated.

Our research seeks to assess the effects of proteolysis in aging Cheddar cheese on the ability to detect milk protein residues by commercial total milk and casein ELISA kits. Because whey proteins have limited and inconsistent presence in Cheddar cheese, evaluation of cheese for whey protein residues was not assessed.

\section{MATERIALS AND METHODS}

\section{Manufacture of Cheddar Cheese}

Cheese was manufactured at a local dairy plant according to standard procedure for New York Cheddar cheese developed by the University of Nebraska-Lincoln Dairy Plant. Briefly, $4,100 \mathrm{~kg}$ of raw milk (3.7\% butterfat) from Holstein cows was pasteurized by HTST on location. The milk was pumped into a $37,850-\mathrm{L}$ capacity steam-jacketed stainless steel cheese vat in the production facility. Once the vat was filled with 2,100 $\mathrm{kg}$ of milk, $1 \mathrm{~kg}$ of freeze-dried direct-to-vat starter culture (Vivopel MSM 960, Vivolac, Greenfield, IN) was added, and the inoculated milk was pre-ripened for 1 $\mathrm{h}$ at $32^{\circ} \mathrm{C}$. Next, $400 \mathrm{~g}$ of double-strength fermentation produced chymosin was added and the mixture was stirred for 25 min or until curd was set. After the curd was set (approximately 25 min after chymosin ad- dition), the curd was cut with $1 / 2$ inch-spaced wire mesh and was allowed to rest for $15 \mathrm{~min}$. Curds were then cooked at $38^{\circ} \mathrm{C}$ with slow stirring. Once the whey acidity had reached the appropriate level after cutting, the whey was drained. Upon completion of draining, matted curd was cut into wide slabs for cheddaring. Slabs were rotated every 15 min until the appropriate acidity was reached, at which time slabs were milled and salted (11 kg of salt added). Milled curds were pressed into $9.1-\mathrm{kg}$ cheese hoops and held under pressure at $280 \mathrm{kPa}$ overnight at 8 to $10^{\circ} \mathrm{C}$. A 9-kg hoop of Cheddar cheese was transported from the production facility to the University of Nebraska-Lincoln Dairy Plant for packaging and aging. The cheese was cut and vacuum-packaged into eighty $100-\mathrm{g}$ blocks and placed into a dedicated cheese cooler for ripening at 4.5 to $6.7^{\circ} \mathrm{C}$.

\section{Sampling of Cheddar Cheese During Aging}

Samples were collected at 2 wk and 1, 2, 4, 6, 8, 13, 19, and 24 mo of aging. At each sampling point, four 100-g blocks of cheese were randomly selected and removed from the cheese cooler. Each of the 4 blocks was cut in half and 1 half was shredded using a finetexture grater attachment with a 13-cup KitchenAid Food Processor (KitchenAid, Benton Harbor, MI). Shredded cheese was mixed and portioned into 10-g aliquots in plastic zip-top bags. The remaining portions of the blocks were resealed and placed into plastic zip-top bags. All samples were transferred to a $-20^{\circ} \mathrm{C}$ freezer for storage until the time of analysis.

\section{Sample Preparation for SDS-PAGE and ELISA Analyses}

Approximately $30 \mathrm{~g}$ of each finely grated and aged cheese sample was removed from the $-20^{\circ} \mathrm{C}$ freezer and pulverized to a fine powder using a Spex 6850 CentriPrep Freezer/Mill (Metuchen, NJ). Samples to be analyzed by SDS-PAGE were prepared as follows. Briefly, $5 \mathrm{~g}$ of freezer-milled cheese was weighed into a 50-mL Falcon tube, and $20 \mathrm{~mL}$ of $5 \%$ sodium chloride solution was added. Extraction buffer of 5\% sodium chloride was used, as it was determined from preliminary experiments to provide superior protein extraction to other buffers evaluated. The sample was mixed using a pulse vortex technique for approximately $5 \mathrm{~s}$. Samples were extracted with horizontal shaking for $60 \mathrm{~min}$ at $22^{\circ} \mathrm{C}$ on a Barnstead Thermolyne LabQuake Shaker (ThermoScientific, Asheville, NC) and centrifuged at $2,900 \times g$ for 30 min at $10^{\circ} \mathrm{C}$ in an IEC Centra MP4R Centrifuge (International Equipment Company, Need- 
ham Heights, MA). The aqueous layer was removed to a new $50-\mathrm{mL}$ tube, whereas pellets and fat layers were discarded and extracts were frozen at $-20^{\circ} \mathrm{C}$ until time of analysis.

Samples analyzed by ELISA were defatted by hexane extraction before dissolution. Briefly, $20 \mathrm{~g}$ of freezermilled cheese was weighed into a 500-mL Erlenmeyer flask. Approximately $180 \mathrm{~mL}$ of cold hexane $\left(-20^{\circ} \mathrm{C}\right)$ was added to the flask. Flasks were placed in an ice bath on a horizontal shaker. Flasks were shaken for 30 min at $50 \%$ max speed. The aqueous layer was decanted and the remaining sample was retained. Two additional hexane washes were performed, for three $-20^{\circ} \mathrm{C}$ hexane washes. The final wash was gravity filtered through fluted Whatman Size 1 filter paper (Whatman International, Ltd., Maidstone, UK) into a glass funnel. The filter and retained cheese were removed from the glass funnel and were dried overnight in a fume hood. Dried defatted cheese was stored in plastic zip-top bags at $-20^{\circ} \mathrm{C}$ until time of analysis.

Prior to ELISA analysis, $1 \mathrm{~g}$ of each aged defatted cheese was suspended in a $5 \%$ sodium chloride solution at a 1:10 (wt/vol) ratio in a 50-mL Falcon tube. Tubes were shaken horizontally for $3 \mathrm{~h}$ at room temperature. Extracts of defatted cheese were centrifuged at 2,900 $\times$ $g$ for $30 \mathrm{~min}$ at $10^{\circ} \mathrm{C}$ and the aqueous layer was removed and reserved in a clean 50-mL Falcon tube, where it was frozen at $-20^{\circ} \mathrm{C}$ until further use.

\section{Protein Concentration of Extracts}

The protein concentrations of the extracts were assessed by 3 different methods. First, the soluble protein concentration of $5 \%$ sodium chloride extracts was determined using the Lowry protein assay as adapted for application in a 96-well microtiter plate using BSA (Pierce Scientific, Rockford, IL) standard (Lowry et al., 1951). Additionally, the UV absorbance of extracts was measured at 260 and $280 \mathrm{~nm}$ using a NanoDrop 2000c Spectrophotometer (Thermo Scientific, Rockford, IL). The 260 -to- $280 \mathrm{~nm}$ ratio was used to estimate the protein concentration using the Warburg-Christian equation (Warburg and Christian, 1942). Finally, the Microtannin Protein Assay was also used to measure protein concentration, performed according to published procedures and modifications (Mejbaum-Katzenellenbogen and Dobryszycka, 1959; Trayer and Trayer, 1988). All samples were analyzed in duplicate, and the standard solutions were prepared and analyzed in triplicate. Sample absorbances in the MicroLowry and Microtannin assays were measured using a BioTek EC808x Microplate Reader and KC Junior Software (BioTek, Winooski, VT). The standard curve was constructed in GraphPad Prism (version 4.03, GraphPad Software
Inc., La Jolla, CA) and the concentration of unknown samples was interpolated from the curve.

\section{Electrophoresis}

Proteins were prepared under reducing conditions according to the procedure of Laemmli (1970). Briefly, 50 $\mu \mathrm{L}$ of each sample was boiled in a $100^{\circ} \mathrm{C}$ water bath in Laemmli sample buffer containing $5.4 \%$ dithiothreitol (wt/vol) for 5 min. Protein separation was performed using $18 \%$ Tris-HCl precast polyacrylamide Ready Gels for Mini-Protean Systems in a Mini-Protean Tetracell electrophoresis unit (Bio-Rad Laboratories, Hercules, CA). Bio-Rad Precision Plus Protein Dual X-tra Standard was used as the protein molecular weight standard for electrophoresis gels (Bio-Rad Laboratories). Gels were loaded with $10 \mu \mathrm{g}$ of protein per lane. The approximate loading volumes were determined by the averaged protein concentrations, as determined by the Lowry protein assay. Empty lanes were filled with $5 \mu \mathrm{L}$ of sample buffer to improve profile quality. Gels were run at a constant voltage of $200 \mathrm{~V}$ for approximately $30 \mathrm{~min}$, or until the dye front reached the bottom of the gel.

Gels were fixed for 30 min in a solution of $60 \%$ trichloroacetic acid (wt/vol) and $17.5 \% 5$-sulfosalicylic acid (wt/vol) diluted 1:5 with deionized water. Fixed gels were rinsed in deionized water and stained overnight using Coomassie Brilliant-Blue R-250 Staining Solution (Bio-Rad Laboratories). After approximately $8 \mathrm{~h}$ of staining, gels were destained using the Coomassie Brilliant Blue R-250 Destaining Solution. Destained gels were imaged using Kodak Gel Logic 440 Imaging System (Eastman Kodak, Rochester, NY) and evaluated using Carestream Imaging software (v5.02.30, Carestream Health, Rochester, NY).

\section{ELISA Analysis}

Neogen Veratox Casein and Total Milk ELISA kits were purchased from Neogen Corporation (Lansing, MI). The ELISA Systems Casein kits were obtained from ELISA Systems (Windsor, Queensland, Australia); R-Biopharm Ridascreen Fast Casein kits were obtained from a distributor (Washington, MO).

Prior to analysis by the 4 commercial ELISA kits, $1 \mathrm{~mL}$ of each defatted Cheddar cheese extract was diluted 1:100 ( $\mathrm{vol} / \mathrm{vol})$ in 5\% sodium chloride solution. Sample preparation and ELISA analysis were performed according to the manufacturer's instructions for $1 \mathrm{~mL}$ of homogeneous liquid sample. Briefly, $1 \mathrm{~mL}$ of diluted sample was added to the appropriate amount of prepared and pre-heated $\left(60^{\circ} \mathrm{C}\right)$ extraction solution. Extractions were performed in a $60^{\circ} \mathrm{C}$ Julabo SW22 
Shaking Waterbath (Julabo USA, Allentown, VA) for the recommended time. Each sample was extracted in triplicate. Samples were cooled to room temperature and $1 \mathrm{~mL}$ of each extraction was centrifuged at the speed, duration, and temperature recommended by the manufacturer-provided product insert in a Thermo Scientific Legend Micro 17 centrifuge (Dubuque, IA). Additional dilutions were performed in the extraction buffer provided by corresponding kits so that absorbance values were within the manufacturer-provided standard curve ranges.

For each ELISA, $100 \mu \mathrm{L}$ of extracted and diluted sample was added to 3 wells of the antibody-coated microtiter plate provided by each kit manufacturer. Samples were incubated for $10 \mathrm{~min}$ and wells were washed the appropriate number of times with prepared manufacturer-provided wash buffer solution. Excess buffer was removed from wells by tapping the inverted plate on an absorbent paper towel repeatedly. Then, $100 \mu \mathrm{L}$ of conjugate antibody solution was added to wells and the plate was allowed to incubate for an additional $10 \mathrm{~min}$. Washing was repeated and $100 \mu \mathrm{L}$ of substrate was added to each well, followed by a final 10-min incubation period to develop a colorimetric reaction. Finally, $100 \mu \mathrm{L}$ of acidic stop solution was added to the wells, and the absorbance of each well was measured using a Dynex Spectra MR Plate Reader (Dynex Technologies, Chantilly, VA) at the manufacturer-recommended wavelength. The concentration of analyte in each sample was interpolated from the standard curve.

Samples that contained concentrations of detectable milk proteins that fell outside the dynamic range of the kits were diluted with the manufacturer-provided extraction buffer until their concentration was quantifiable. Dilution factors were applied to the detected value of milk protein residue to determine a final concentration for each sample. The ranges of quantitation and other kit information used in the study are listed in the Appendix (Table A1).

Data analysis was performed in Microsoft Excel (Microsoft Corp., Redmond, WA), GraphPad Prism (version 4.03), SAS (version 9.4, SAS Institute Inc., Cary, NC), and manufacturer-provided software, if any. Analysis of the MicroLowry, absorbance at $280 \mathrm{~nm}$ $\left(\mathbf{A}_{280}\right)$, and Microtannin methods was performed using the F-test for variance, Student's $t$-test, the 1 - and 2-way ANOVA, and Tukey's multiple comparison test. The Neogen Veratox Software (version 3.02) was used to analyze data obtained with the Neogen kits, whereas the R-Biopharm Ridawin Software (version 1.42) was used to evaluate R-Biopharm data. Criteria for acceptable ELISA kit performance included an $R^{2}$ of $\geq 0.98$ for the standard curve and a coefficient of variation of $\leq 20 \%$.

\section{RESULTS AND DISCUSSION}

\section{Protein Concentration of Extracts}

Three assays, the Lowry method, $\mathrm{A}_{280}$, and the Microtannin protein assay, were used to determine the protein concentration of $5 \%$ sodium chloride-soluble extracts of cheese samples. Some uncertainty exists relative to the optimal method to use to determine the protein content of aging cheeses. Caseins are differentially sensitive to proteolysis. As cheese is fermented, $\alpha-\mathrm{CN}$ is among the first to be hydrolyzed. The N-terminal residues of $\alpha_{\mathrm{S}^{-}}$ $\mathrm{CN}$ that are released early in the aging process do not contain Tyr or Trp residues and the peptides do not absorb UV light. Even though proteolysis has occurred, a corresponding change in absorbance at $\mathrm{A}_{280}$ is not necessarily observed (Marcos et al., 1979). The Lowry method is a dye-binding assay that relies on intact protein fragments containing aromatic AA residues for quantitation (Lowry et al., 1951). The $\mathrm{A}_{280}$ assay can be affected by interference from several sources, and using UV absorbance has been suggested to be a potentially problematic method for analyzing ripening cheeses (Wallace and Fox, 1998). As aging occurs in cheese, a decrease in detected intact proteins would be observed, with a corresponding increase in peptides and free AA. These methods would be expected to show trends in aging progression dependent on protein and peptide solubility.

Results of the Lowry assay displayed a variable trend in the concentration of $5 \% \mathrm{NaCl}$-soluble protein, with peaks observed at 2, 6, and 24 mo of aging (Table 1). The lowest levels of soluble protein were observed at $0.5,8$, and 19 mo of aging. The measured concentration remains relatively stable between 8 and 19 mo of aging; among these samples, the variation is roughly $5 \%(P$ $>0.05$ ).

According to UV absorbance data measured at 280 $\mathrm{nm}$, the concentration of soluble protein is greater at the end of aging (24-mo Cheddar) than at the onset $(0.5$ mo; $P<0.001)$. With the Microtannin protein assay, a decrease was observed in $5 \% \mathrm{NaCl}$-soluble protein as aging progressed $(P<0.001)$. A peak in soluble protein content was observed at 2 mo of aging, in agreement with the results observed with the Lowry protein method $(P<0.001)$.

The differing results among the assays were expected because the Lowry and $\mathrm{A}_{280}$ assays rely on intact proteins to determine concentration, whereas the Microtannin assay can detect both intact proteins and 
free AA. In cheese, proteolytic enzymes release small peptides and AA throughout aging. Increasing levels of proteolysis generally correspond to an increased concentration of free AA and a decrease in intact protein in sample extracts, although this is not always observed among cheese varieties (Kuchroo and Fox, 1982). In general, the Lowry assay is considered more accurate in measuring protein concentration than the $\mathrm{A}_{280}$ method or the Microtannin method (Chang, 2010). Although the assays did not vary in concentration significantly from each other, they are based on different standard curves and different chemical reactions for estimating protein content and, therefore, cannot be averaged.

In recent years, the Microtannin method has lost favor for use in determining protein concentrations of foods, as some authors have described the proper interpretation of the method is not a measure of the concentration of protein precipitated, but rather the concentration of phenols in a sample (Hagerman, 2012). The $A_{280}$ method, although still commonly used for determining relative protein concentration in samples, is not as sensitive as the Lowry method (Olson and Markwell, 2007; Chang, 2010). Using the Lowry method, it was determined that the detected concentration of proteins did not change significantly over the course of 24 mo of aging $(P>0.05)$.

\section{SDS-PAGE}

Polyacrylamide gels were run at conditions described above. Samples were split among 2 gels (10 lanes per

Table 1. Effect of aging on soluble protein concentrations (mean \pm $\mathrm{SEM} ; \mu \mathrm{g} / \mu \mathrm{L})$ in $5 \%$ (wt/vol) sodium chloride extracts of Cheddar cheese aged 0.5 to $24 \mathrm{mo}$

\begin{tabular}{lccc}
\hline & \multicolumn{3}{c}{ Protein assay } \\
\cline { 2 - 4 }$(\mathrm{mge})$ & MicroLowry $^{1}$ & $\mathrm{~A}_{280}{ }^{2}$ & Microtannin $^{3}$ \\
\hline 0.5 & $9.1 \pm 0.1^{\mathrm{a}}$ & $5.2 \pm 0.01^{\mathrm{a}}$ & $10.2 \pm 0.7^{\mathrm{a}}$ \\
1 & $10.7 \pm 0.8^{\mathrm{ab}}$ & $5.4 \pm 0.02^{\mathrm{b}}$ & $9.0 \pm 0.1^{\mathrm{b}}$ \\
2 & $12.5 \pm 0.9^{\mathrm{b}}$ & $6.6 \pm 0.05^{\mathrm{c}}$ & $11.2 \pm 0.3^{\mathrm{c}}$ \\
4 & $10.8 \pm 0.2^{\mathrm{ab}}$ & $6.8 \pm 0.20^{\mathrm{b}}$ & $9.3 \pm 0.3^{\mathrm{b}}$ \\
6 & $14.7 \pm 0.7^{\mathrm{c}}$ & $7.8 \pm 0.04^{\mathrm{d}}$ & $8.5 \pm 0.1^{\mathrm{d}}$ \\
8 & $8.9 \pm 0.7^{\mathrm{a}}$ & $7.1 \pm 0.02^{\mathrm{e}}$ & $7.8 \pm 0.1^{\mathrm{e}}$ \\
10 & $9.4 \pm 0.8^{\mathrm{a}}$ & $6.8 \pm 0.12^{\mathrm{f}}$ & $6.5 \pm 0.2^{\mathrm{f}}$ \\
13 & $9.4 \pm 0.5^{\mathrm{a}}$ & $6.7 \pm 0.06^{\mathrm{f}}$ & $6.4 \pm 0.05^{\mathrm{f}}$ \\
19 & $9.1 \pm 0.4^{\mathrm{a}}$ & $7.2 \pm 0.03^{\mathrm{g}}$ & $5.5 \pm 0.4^{\mathrm{g}}$ \\
24 & $12.2 \pm 0.9^{\mathrm{b}}$ & $7.2 \pm 0.08^{\mathrm{g}}$ & $5.3 \pm 0.2^{\mathrm{g}}$ \\
\hline
\end{tabular}

${ }^{\mathrm{a}-\mathrm{g}}$ Within columns, values followed by the same superscript were not significantly different $(P<0.05)$.

${ }^{1}$ The MicroLowry assay is described by Lowry et al. (1951) and modified by Trayer and Trayer (1988). The MicroLowry assay estimates protein concentration by measuring the concentration of dye-bound aromatic AA.

${ }^{2} \mathrm{~A}_{280}$ indicates the measured absorbance of the sample when exposed to light at $280 \mathrm{~nm}$.

${ }^{3}$ The Microtannin assay (Mejbaum-Katzenellenbogen and Dobryszycka, $1959)$ is capable of detecting intact proteins and free AA. gel), and are displayed in Figure 1. Protein degradation was observed throughout aging, as displayed with the changes in band intensity as aging continues. The bands displayed in the 24-mo Cheddar extract are distinctly less prominent than the protein bands observed in samples from earlier stages of aging (Figure 1). The casein bands, observable between 20 and $30 \mathrm{kDa}$, show a dramatic decrease in intensity over time (Figures $1 \mathrm{~A}$ and $1 \mathrm{~B}$, region $\mathrm{C}$ ). Low-molecular-weight peptides increase throughout aging, as shown by an increase in intensity of residues below the $10-\mathrm{kDa}$ molecular weight marker (Figures 1A and 1B, region E).
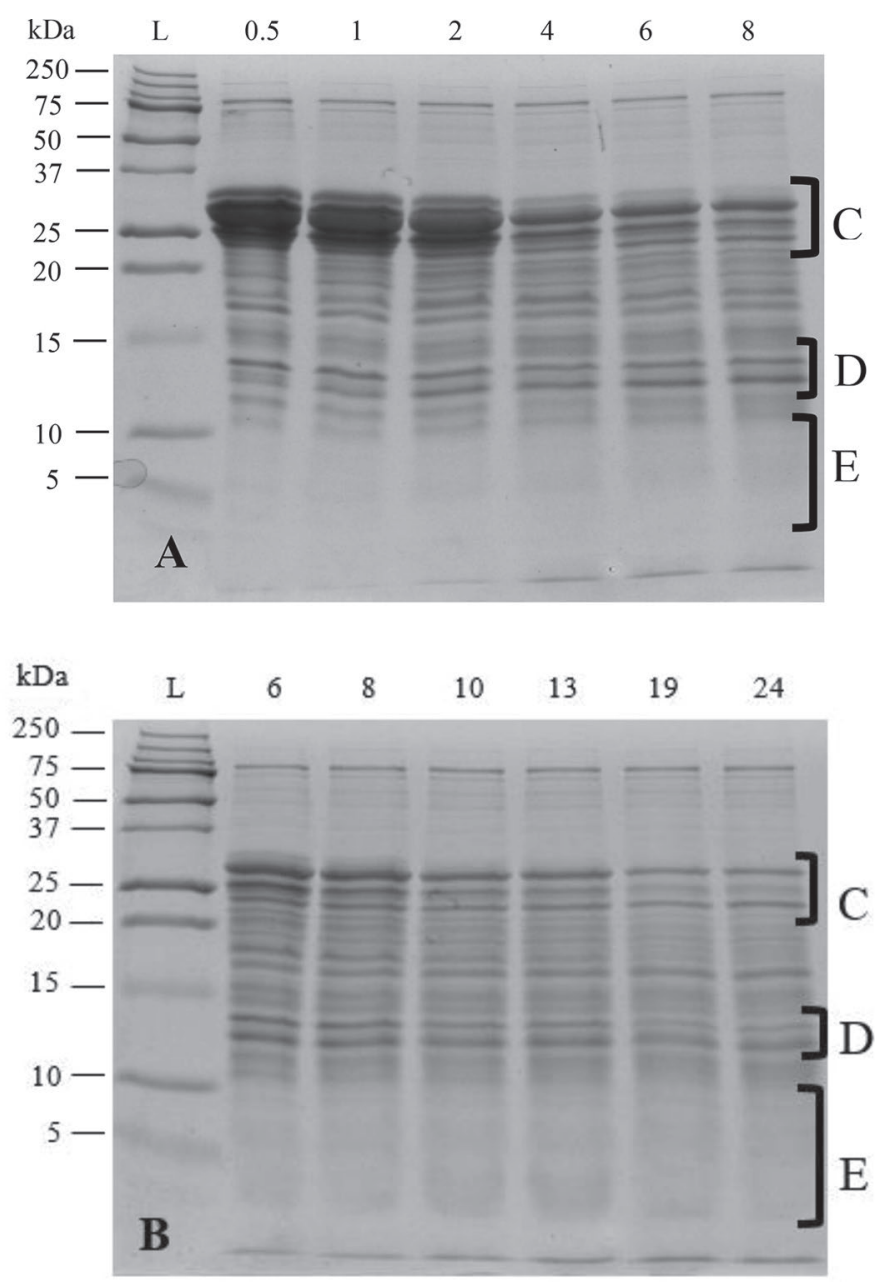

Figure 1. The SDS-PAGE profiles for $5 \%$ sodium chloride extracts of Cheddar cheese aged 0.5 to 24 mo. Gels were run at $200 \mathrm{~V}$ for 35 min. Each well was loaded with $10 \mu \mathrm{g}$ of protein. (A) Lane $\mathrm{L}=$ molecular weight ladder; all other lane labels correspond to the age of the sample in months. (B) Lane $\mathrm{L}=$ molecular weight ladder; all other lane labels correspond to the age of the sample in months. Region $(\mathrm{C})$ on both gels (A) and (B) indicates the intact fragments of $\alpha_{\mathrm{S}^{-}}, \alpha_{\mathrm{S2}^{-}}$, $\beta-$, and $\mathrm{k}-\mathrm{CN}$; region (D) indicates the $12-$ to $13-\mathrm{kDa}$ band of interest described in the text; region (E) indicates the location of migration for lower-molecular-weight proteins and peptides. 
In agreement with the data obtained from the protein concentration assays, we found an increase in band intensity at the 2-mo time point, observable as a band migrating in the 12 to $13 \mathrm{kDa}$ range (Figures $1 \mathrm{~A}$ and $1 \mathrm{~B}$, region $\mathrm{D})$. Where a peak in soluble protein was observed in the Lowry and $\mathrm{A}_{280}$ assays in the 6-mo Cheddar cheese extract, only a small increase in band intensity is observed in the 12 to $13 \mathrm{kDa}$ range (Figure 1A, Lane 6); however, large decreases in band intensities around $15 \mathrm{kDa}$ and within the intact casein region $(27-30 \mathrm{kDa})$ were observed between the 4- and 6-mo Cheddar samples. Because protein solubility differs, it is likely that products of primary proteolysis would increase in the first several months of aging and have the potential to be degraded during the later months of aging.

Proteolysis of para- $\kappa-\mathrm{CN}$ is documented to occur during cheese manufacture, but only to a limited extent during ripening (Grappin et al., 1985). Electrophoretic analyses reveal a band near the $16-\mathrm{kDa}$ marker that may correspond with para- $\kappa-\mathrm{CN}$. The intensity of this band remains visually consistent throughout aging.

The chymosin-induced hydrolysis of $\kappa-\mathrm{CN}$ into para-k-CN and glycomacropeptide fragments (Grappin et al., 1985) is the first proteolytic event occurring in cheesemaking; this hydrolysis destabilizes the casein micelle and initiates the coagulation of curd and separation of whey. Commercial cheese manufacturers have largely adopted proteases of microbial origin for their chymosin activity. Meanwhile, traditional cheese manufacture, especially in European areas, continues to employ calf-derived chymosin for coagulation in the production of cow milk cheese (Fox et al., 2015). Primary proteolysis encompasses any proteolytic activity on native caseins that results in the production of peptides and free AA (Fox et al., 2004). In addition to the hydrolysis of $\kappa-\mathrm{CN}$, residual chymosin in cheese curd may also hydrolyze $\alpha_{S_{1}}$ CN (Fox, 1989). Experiments evaluating hydrolysis of caseins in cheese have shown that $\alpha_{\mathrm{S}_{1}} \mathrm{CN}$ is completely hydrolyzed by chymosin within 3 to 4 mo of ripening based on urea-PAGE (Fox et al., 2015). In contrast, para- $\kappa-$ and $\beta-\mathrm{CN}$ are resistant to hydrolysis by chymosin during ripening (Møller et al., 2012). Chymosin activity diminishes with aging; the rate of activity is dependent upon cheese variety and other biochemical characteristics, such as moisture content, salt, $\mathrm{pH}$, and temperature, during the cooking and ripening.

Plasmin, an indigenous milk proteinase, preferentially hydrolyzes $\beta$-CN to smaller peptides during cheese ripening, with approximately $50 \%$ of the initial $\beta-\mathrm{CN}$ remaining at 6 mo of aging (Fox et al., 2015). Due to its hydrophobicity, $\beta$-CN does not undergo complete hydrolysis during ripening (O'Keeffe et al., 1976). Plas- min is additionally rapidly hydrolytic toward $\alpha_{S_{2}}-\mathrm{CN}$ and exhibits slow hydrolysis on $\alpha_{\mathrm{S1}^{-}} \mathrm{CN}$. Plasmin has no apparent hydrolytic effects on $\kappa$-CN.

Nonstarter bacteria are less common in cheeses made from pasteurized milk at the onset of ripening. However, at approximately 2 mo of aging, nonstarter bacteria multiply in population to approximately $10^{7}$ to $10^{8}$ cfu/g (Fox et al., 2015). The population of the starter microflora declines during this time, as preferred substrates become more limited and nonstarter bacteria dominate to degrade peptides and other products of primary proteolysis into free AA and smaller peptides during secondary proteolysis (Rank et al., 1985; Fox et al., 2004, 2015).

The variable concentrations of protein measured in cheese extracts during aging are likely explained by the changing solubility of proteins and peptides. As proteins and peptides are denatured, the exposure of different AA causes changes in solubility and molecular interactions. With respect to extraction of peptides in buffers, changes in solubility will drive changes in both the overall concentration of protein and in profiles. The hydrophobic residues of $\beta$-CN would not be completely extractable from samples. Additionally, $\alpha_{\mathrm{S}_{1}} \mathrm{CN}$ is quickly hydrolyzed into $\alpha_{\mathrm{S} 1}-\mathrm{I}-\mathrm{CN}$ and other fragments in Cheddar cheese, exposing free hydrophobic and hydrophilic residues on the proteins. Therefore, the data from the SDS-PAGE analysis and the protein concentration assays suggest that a drop or peak in protein concentration does not necessarily directly correspond with a decrease or increase in band intensity on the gel. Rather, the change of solubility of proteins and peptides because of proteolytic activity drives changes in their molecular interactions and, therefore, their detection using electrophoretic methods.

\section{ELISA Analysis}

Earlier work has determined the specificities of commercially available milk ELISA kits to purified bovine milk proteins and milk-derived ingredients (Ivens et al., 2016). Commercial ELISA kits are differentially sensitive to various milk proteins and are not capable of detecting all proteins present in bovine milk. The Neogen Veratox Casein kit is specifically sensitive to $\alpha$ and $\beta$-CN. Preliminary analyses with purified protein fractions revealed that this kit detects and quantifies the presence of both proteins with nearly $100 \%$ accuracy (Ivens et al., 2016). The ELISA Systems Casein kit is specifically sensitive to $\alpha-\mathrm{CN}$, at approximately $90 \%$ accuracy in estimating the actual quantity present in the sample; the kit does not detect $\beta$ - and $\kappa-\mathrm{CN}$. The R-Biopharm Ridascreen Fast Casein kit primarily detects $\mathrm{k}$-CN with near 100\% accuracy, but also detects 


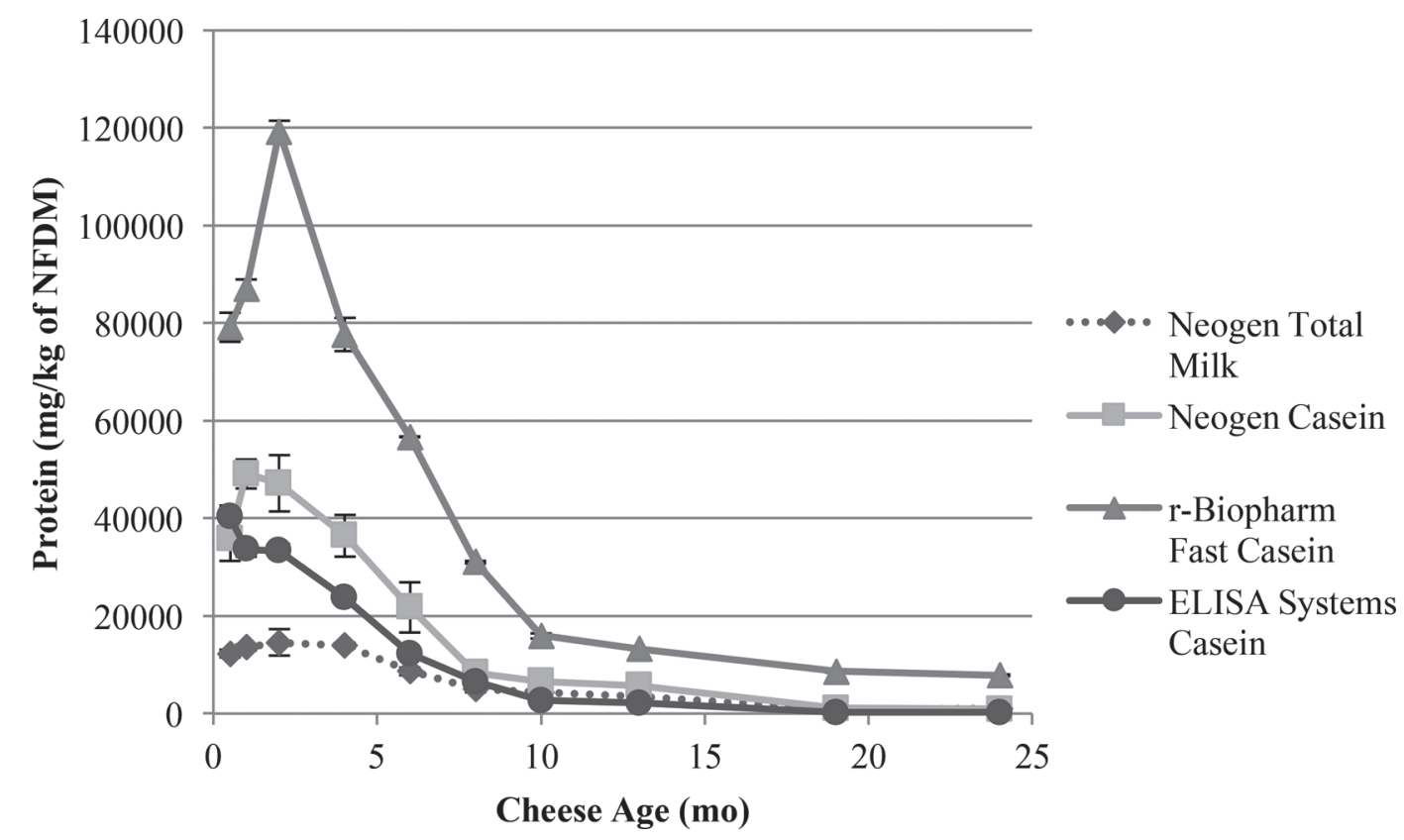

Figure 2. Detection of milk protein residues in Cheddar cheese aged 0.5 to 24 mo by commercial ELISA kits. All detected concentrations are reported in units of $\mathrm{mg} / \mathrm{kg}$ of nonfat dry milk (NDFM). Error bars indicate mean \pm SE. Neogen Veratox Casein and Total Milk ELISA kits were purchased from Neogen Corporation (Lansing, MI). The ELISA Systems Casein kits were obtained from ELISA Systems (Windsor, Queensland, Australia); R-Biopharm Ridascreen Fast Casein kits were obtained from a distributor (Washington, MO).

some $\beta$-CN at approximately $10 \%$ of the level actually present. The Neogen Veratox Total Milk kit is primarily sensitive to $\mathrm{k}-\mathrm{CN}$ (at $50 \%$ of the actual concentration), but also detects some $\alpha$ - and $\beta$-CN (at approximately $10 \%$ of the actual levels).

Using the Neogen Veratox Total Milk kit, a substantial decrease in detection of milk protein residues, expressed as nonfat dry milk, was observed with increasing cheese age; however, milk protein residues remained detectable even after 24 mo of aging. Over the course of aging, milk protein detection was reduced by more than $90 \%$, with $93 \%$ of signal lost between the highest (2 mo) and the lowest (19 mo) detection points (Figure 2).

During Cheddar cheese aging, an increase in the detection of milk proteins was observed after 2 and 4 mo of aging in comparison to the earlier sampling points. The increase in detection of milk proteins at the 2-mo time point was followed by decreases in detection for the remainder of the aging process. When comparing ELISA results to the levels of soluble protein throughout aging, we noted a comparable peak in detection at the 2-mo time point. However, comparable results between residual milk protein detection by ELISA and soluble protein were not observed after 6 mo of aging.

As the Neogen Total Milk kit is primarily sensitive to $\kappa$ - $\mathrm{CN}$, the peak in detection of milk protein residues in the 2-mo Cheddar sample suggests an increase in solubility or an increase in exposure of previously hidden $\kappa$-CN epitopes (Ivens et al., 2016). The subsequent loss of detection is likely due to hydrolysis of the $\kappa$-CN epitopes with cheese aging.

A similar trend was observed with the Neogen Veratox Casein kit as was observed with the Neogen Veratox Total Milk kit (Figure 2). A peak in detectable milk protein residues was observed for Cheddar cheese aged for 2 mo. Over the course of aging, the detection of casein residues using the Neogen Veratox Casein kit decreased by $97 \%$. The increase in detectable milk protein residues observed in the cheese between 2 and 8 wk of aging may be a result of either proteolytic exposure of previously hidden linear epitopes or increased solubility of proteins and peptides targeted by the kit antibodies or both.

As previously noted, the Neogen Veratox Casein kit quantifies milk protein residues primarily based on $\alpha$ and $\beta-\mathrm{CN}$ detection. The peak in detection of casein residues in the 1- and 2-mo Cheddar samples would therefore suggest an increase in detectable $\alpha$ - or $\beta$-CN residues. Whereas the Neogen Veratox Casein and Total Milk kits detect different casein fractions, similar trends are displayed in the detection of residual milk proteins in Cheddar cheese over time with both kits.

A similar trend was also observed using the R-Biopharm Ridascreen Fast Casein kit as with the 2 Neogen 
Veratox kits in that a peak in detectable milk protein residues occurred in the 2-mo aged Cheddar sample, followed by a decrease in detectable milk protein residues. The lowest level of detectable milk protein residues occurs after 24 mo of aging, with a $90 \%$ decrease in signal between the initial Cheddar sample (2 wk) and the 24-mo Cheddar sample. The similarity in results to the Neogen Veratox Total Milk kit is not surprising, as both kits primarily detect $\kappa-\mathrm{CN}$. Thus, as before, the increase in detectable milk protein residues in the 2-mo Cheddar sample can be explained by the liberation or increased solubility of $\kappa-\mathrm{CN}$ (or $\beta-\mathrm{CN}$ ) residues due to proteolysis.

Unlike the other 3 ELISA kits evaluated, the ELISA Systems Casein kit did not detect a peak in milk protein residues in the 2-mo Cheddar cheese sample (Figure 2). However, a decreasing trend in detection was observed throughout aging, as was also observed with the other evaluated ELISA kits. With the ELISA Systems Casein kit, a $99 \%$ decrease in detection of milk protein residues was observed between the 2-wk and 24-mo samples. As previously noted, the ELISA Systems Casein kit relies strictly on the detection of $\alpha_{\mathrm{s}}$-CN for quantitation.

Because no peak was observed in the detection of milk protein residues in the 2-mo sample of Cheddar cheese with the ELISA Systems Casein kit, the evidence initially suggests that the peaks observed with the other kits may be a result of increased solubility or revealed epitopes of $\beta$ - or $\kappa-\mathrm{CN}$. In contrast, the ELISA Systems Casein kit result seems to indicate continuous degradation of $\alpha_{\mathrm{s}}$-CN or its epitopes without exposure of additional epitopes detected by the kit. Although it is possible that the proteolysis that occurs during Cheddar cheese manufacture and aging decreases the solubility of proteins, the native structure of caseins is largely linear suggesting that proteolysis would likely not dramatically decrease solubility. Thus, the results more likely indicate that the ELISA Systems Casein kit was developed using antibodies that recognize intact and easily proteolyzed epitopes of $\alpha-\mathrm{CN}$ that are progressively lost during aging.

In contrast to the results observed with the Lowry protein assays, no peak in detection of milk protein residues was observed in the 6-mo Cheddar cheese sample with any of the evaluated ELISA kits. However, all protein assays (Lowry, $\mathrm{A}_{280}$, and Microtannin) exhibited a peak in protein concentration in the 2-mo Cheddar sample, as was detected with the Neogen Veratox Total Milk and Casein kits and the R-Biopharm Ridascreen Casein kit. These observations indicate that the soluble and detectable residues vary as cheese aging progresses. Overall, results from all evaluated kits indicate that the detectable levels of milk protein residues in Cheddar cheese decrease throughout the 2 yr of aging, with a 90 to $99 \%$ reduction in detection occurring as aging continues. Even with this decrease, however, milk protein residues are still detectable at the most advanced stage of Cheddar cheese ripening. The $\alpha_{\mathrm{S1} \text { - }}$ $\mathrm{CN}$ was degraded substantially more than other caseins during Cheddar cheese ripening, attributable to the residual action of chymosin during primary proteolysis (Grappin et al., 1985; Singh et al., 1995). According to ELISA results, the kit that relies exclusively on detection of $\alpha_{\mathrm{S} 1-} \mathrm{CN}$ epitopes, ELISA Systems Casein, exhibits the most dramatic decrease in detection during ripening (99\%). Additionally, this is the only kit of those tested that displayed a progressive decrease in the detection of milk protein residues throughout aging, with no large observed peaks. This kit, therefore, may uniquely offer an excellent approach to the monitoring of cheese proteolysis, and especially the loss of native $\alpha_{S 1-}$ CN structure. Møller et al. (2012) described that at the completion of a $270-d$ ripening cycle, $\alpha_{\mathrm{S} 1-} \mathrm{CN}$ had degraded to approximate completion. In contrast, it was reported that para- $\kappa-\mathrm{CN}$ remained very resistant to hydrolysis during ripening, and that about $50 \%$ of $\beta$-CN remained intact after 270 d (Børsting et al., 2012; Møller et al., 2012).

Whereas both the Neogen Veratox Total Milk and the R-Biopharm Ridascreen Fast Casein kits were capable of detecting and quantifying $\kappa-\mathrm{CN}$, the R-Biopharm kit detected a higher concentration of milk protein residues in aging Cheddar cheese throughout the study (Figure 2 ). Previous work indicated that the R-Biopharm kit detected residues of $\kappa$-casein with near 100\% accuracy, whereas the Neogen Veratox Total Milk kit displayed roughly $50 \%$ accuracy for quantitation of purified $\kappa-\mathrm{CN}$ (Ivens et al., 2016). This observation may indicate that the kit targets an epitope stable to proteolysis in Cheddar cheese manufacture and ripening. Para-k-CN is not broken down during cheese ripening, so the degradation observed by the kits may be a result of casein glycomacropeptide fragment (1-105) (Rank et al., 1985). The variable specificities of the commercial milk ELISA kits and the results obtained in the analysis of aging Cheddar cheese samples suggest that milk ELISA with specificities toward different milk proteins and epitopes may be useful in monitoring the progress of proteolysis during cheese aging.

This research highlights the importance of understanding the limitations of ELISA kits for the detection of allergen residues in food products. In this case, fermentation and cheese ripening were shown to have major effects on the detection of milk protein residues in aged Cheddar cheese. In part, this finding is not especially surprising because the antibodies in commer- 
cial ELISA kits are often oriented toward the detection of intact milk proteins, whereas the proteins in aged Cheddar cheese have been subjected to considerable proteolysis. None of the current commercially available milk ELISA methods are validated specifically for milk allergen detection in fermented foods. The dramatic loss in the ability of the antibodies in these kits to detect milk proteins between young and aged cheese may be a cause for some concern. Although high concentrations of Cheddar cheese are detected with current commercially available ELISA kits, low concentrations of aged or highly proteolyzed cheese will be a challenge to reliably detect and quantify. The recovery of trace amounts of aged cheese in various common food matrices has not been assessed by ELISA methods. The importance of cross contact between cheese and other processed food products has not been fully assessed but may be difficult to completely examine with current commercial ELISA kits. The construction of milk ELISA kits capable of detecting fermentation-stable milk epitopes would seem to offer a path toward development of improved methods.

The comparative allergenicity of cheese compared with milk toward milk-allergic individuals has not been clinically assessed beyond the study by Alessandri et al. (2012). In their study, the majority of milk-allergic subjects could tolerate the ingestion of aged ParmigianoReggiano cheese. Thus, no conclusion can be reached regarding the correlation between the loss of detection of milk protein residues by ELISA during cheese aging and the allergenicity of the cheese at that stage of aging. Because cheeses vary widely in their manufacture, resulting in differing patterns of milk protein proteolysis, the clinical allergenicity of cheeses is not easily determined. Thus, it seems prudent to assume that cheeses are allergenic to milk-allergic individuals, and that methods that are more robust will be needed for the detection of milk protein and peptide residues from cheeses and other fermented dairy products.

\section{ACKNOWLEDGMENTS}

This project was partially supported by Agriculture and Food Research Initiative Competitive Grant no. 2011-67017-20080 from USDA National Institute of Food and Agriculture (Washington, DC). Additional support was obtained from funding for the Food Allergy Research \& Resource Program (Lincoln, NE), a food industry-funded consortium of more than 80 member companies, and the Agricultural Research Division of the University of Nebraska-Lincoln. The 20-lb block of Cheddar cheese used in this research was donated by Jisa's Farmstead Cheese of Brainard, Nebraska.

\section{REFERENCES}

Alessandri, C., S. Sforza, P. Palazzo, F. Lambertini, S. Paolella, D. Zennaro, C. Rafaiani, R. Ferrara, M. L. Bernardi, M. Santoro, S. Zuzzi, I. Giangrieco, A. Dossena, and A. Mari. 2012. Tolerability of a fully maturated cheese in cow's milk allergic children: Biochemical, immunochemical, and clinical aspects. PLoS One 7:e40945.

Alves, R. C., M. F. Barroso, M. B. González-García, M. B. P. P. Oliveira, and C. Delerue-Matos. 2016. New trends in food allergens detection: Toward biosensing strategies. Crit. Rev. Food Sci. Nutr. 56:2304-2319

Børsting, M. W., K. B. Qvist, M. Rasmussen, J. Vindeløv, F. K. Vogensen, and Y. Ardö. 2012. Impact of selected coagulants and starters on primary proteolysis and amino acid release related to bitterness and structure of reduced-fat Cheddar cheese. Dairy Sci. Technol. 92:593-612.

Cattaneo, S., J. A. Hogenboom, F. Masotti, V. Rosi, L. Pellegrino, and P. Resmini. 2008. Grated Grana Padano cheese: New hints on how to control quality and recognize imitations. Dairy Sci. Technol. 88:595-605.

Chang, S. K. 2010. Protein analysis. Pages 133-146 in Food Analysis Springer, New York, NY.

Deegan, K. C., and P. L. McSweeney. 2013. Effects of low-pressure homogenisation pre-treatment of cheesemilk on the ripening of Cheddar cheese. Dairy Sci. Technol. 93:641. https://doi.org/10.1007/ s13594-013-0139-0.

Di Luccia, A., M. Faccia, C. Incoronato, F. Inglese, C. Lamacchia, S. Lamparelli, M. Occidente, and D. Matassino. 2013. Cheese processing. Pages 247-259 in Proteomics in Foods. Springer, New York, NY

Fox, P., T. Uniacke-Lowe, P. McSweeney, and J. O'Mahony. 2015. Chemistry and biochemistry of cheese. Pages 499-546 in Dairy Chemistry and Biochemistry. Springer, Cham, Switzerland.

Fox, P. F. 1989. Proteolysis during cheese manufacture and ripening. J. Dairy Sci. 72:1379-1400.

Fox, P. F., P. L. H. McSweeney, T. M. Cogan, and T. P. Guinee. 2004 Cheese: Chemistry, Physics and Microbiology: General Aspects. No. 1. Elsevier Science, Amsterdam, the Netherlands.

Grappin, R., T. C. Rank, and N. F. Olson. 1985. Primary proteolysis of cheese proteins during ripening. A review. J. Dairy Sci. 68:531540.

Gutiérrez-Méndez, N., J. C. Rodríguez-Figueroa, A. F. González-Córdova, G. V. Nevárez-Moorillón, B. Rivera-Chavira, and B. VallejoCordoba. 2010. Phenotypic and genotypic characteristics of Lactococcus lactis strains isolated from different ecosystems. Can. J. Microbiol. 56:432-439.

Hagerman, A. E. 2012. Fifty years of polyphenol-protein complexes. Pages 71-91 in Recent Advances in Polyphenol Research. Vol. 3. Wiley-Blackwell, West Sussex, UK.

Hayaloglu, A., and P. McSweeney. 2014. Primary biochemical events during cheese ripening. Pages 134-166 in Dairy Microbiology and Biochemistry: Recent Developments. CRC Press, Boca Raton, FL.

Ivens, K. O., J. L. Baumert, and S. L. Taylor. 2016. Commercial milk enzyme-linked immunosorbent assay (ELISA) kit reactivities to purified milk proteins and milk-derived ingredients. J. Food Sci. 81:T1871-T1878.

Karametsi, K., S. Kokkinidou, I. Ronningen, and D. G. Peterson 2014. Identification of bitter peptides in aged Cheddar cheese. J. Agric. Food Chem. 62:8034-8041.

Kuchroo, C., and P. Fox. 1982. Soluble nitrogen in Cheddar cheese: Comparison of extraction procedures. Milchwissenschaft 37:331335.

Laemmli, U. K. 1970. Cleavage of structural proteins during the assembly of the head of bacteriophage T4. Nature 227:680-685.

Larsen, L. B., A. Wedholm-Pallas, H. Lindmark-Månsson, and A. Andrén. 2010. Different proteomic profiles of sweet whey and rennet casein obtained after preparation from raw versus heat-treated skimmed milk. Dairy Sci. Technol. 90:641-656.

Lowry, O. H., N. J. Rosebrough, A. L. Farr, and R. J. Randall. 1951. Protein measurement with the Folin phenol reagent. J. Biol Chem. 193:265-275. 
Marcos, A., M. A. Esteban, F. León, and J. Fernández-Salguero. 1979. Electrophoretic patterns of European cheeses: Comparison and quantitation. J. Dairy Sci. 62:892-900.

Masotti, F., J. A. Hogenboom, V. Rosi, I. De Noni, and L. Pellegrino. 2010. Proteolysis indices related to cheese ripening and typicalness in PDO Grana Padano cheese. Int. Dairy J. 20:352-359.

Mejbaum-Katzenellenbogen, W., and W. M. Dobryszycka. 1959. New method for quantitative determination of serum proteins separated by paper electrophoresis. Clin. Chim. Acta 4:515-522.

Møller, K. K., F. P. Rattray, W. L. P. Bredie, E. Høier, and Y. Ardö. 2013. Physicochemical and sensory characterization of Cheddar cheese with variable $\mathrm{NaCl}$ levels and equal moisture content. J. Dairy Sci. 96:1953-1971.

Møller, K. K., F. P. Rattray, E. Høier, and Y. Ardö. 2012. Manufacture and biochemical characteristics during ripening of Cheddar cheese with variable $\mathrm{NaCl}$ and equal moisture content. Dairy Sci. Technol. 92:515-540.

O'Keeffe, R. B., P. F. Fox, and C. Daly. 1976. Contribution of rennet and starter proteases to proteolysis in Cheddar cheese. J. Dairy Res. 43:97-107.

Olson, B. J., and J. Markwell. 2007. Assays for determination of protein concentration. Curr. Protoc. Protein Sci. 48:3.4.1-3.4.29. https://doi.org/10.1002/0471140864.ps0304s48.

Parente, E., H. Patel, V. Caldeo, P. Piraino, and P. L. McSweeney. 2012. RP-HPLC peptide profiling of cheese extracts: A study of sources of variation, repeatability and reproducibility. Food Chem. 131:1552-1560.

Rank, T. C., R. Grappin, and N. F. Olson. 1985. Secondary proteolysis of cheese during ripening: A review. J. Dairy Sci. 68:801-805.

Sampson, H. A. 2004. Update on food allergy. J. Allergy Clin. Immunol. 113:805-819.

Sicherer, S. H., and H. A. Sampson. 2010. Food allergy. J. Allergy Clin. Immunol. 125:S116-S125.

Singh, T. K., P. F. Fox, and A. Healy. 1995. Water-soluble peptides in Cheddar cheese: isolation and identification of peptides in the diafiltration retentate of the water-soluble fraction. J. Dairy Res. 62:629-640.

Skripak, J. M., S. D. Nash, H. Rowley, N. H. Brereton, S. Oh, R. G. Hamilton, E. C. Matsui, A. W. Burks, and R. A. Wood. 2008. A randomized, double-blind, placebo-controlled study of milk oral immunotherapy for cow's milk allergy. J. Allergy Clin. Immunol. 122:1154-1160.

Steele, J., J. Broadbent, and J. Kok. 2013. Perspectives on the contribution of lactic acid bacteria to cheese flavor development. Curr. Opin. Biotechnol. 24:135-141.

Stephan, O., and S. Vieths. 2004. Development of a real-time PCR and a sandwich ELISA for detection of potentially allergenic trace amounts of peanut (Arachis hypogaea) in processed foods. J. Agric. Food Chem. 52:3754-3760.

Trayer, H. R., and I. P. Trayer. 1988. Fluorescence resonance energy transfer within the complex formed by actin and myosin subfragment 1. Comparison between weakly and strongly attached states. Biochemistry 27:5718-5727.

Verhoeckx, K. C., Y. M. Vissers, J. L. Baumert, R. Faludi, M. Feys, S. Flanagan, C. Herouet-Guicheney, T. Holzhauser, R. Shimojo, and N. van der Bolt. 2015. Food processing and allergenicity. Food Chem. Toxicol. 80:223-240.

Wal, J., H. Bernard, G. Clément, J. Chatel, and K. Adel-Patient. 2001. Characterization of allergens in milk. Curr. Allergy Clin. Immunol. 14:4-10.

Wallace, J., and P. Fox. 1998. Rapid spectrophotometric and fluorimetric methods for monitoring nitrogenous (proteinaceous) compounds in cheese and cheese fractions: A review. Food Chem. $62: 217-224$

Warburg, O., and W. Christian. 1942. Insulation and crystalisation of the fermenting process of enolase. Biochem. Z. 310:384-421.

Weber, D., P. Raymond, S. Ben-Rejeb, and B. Lau. 2006. Development of a liquid chromatography-tandem mass spectrometry method using capillary liquid chromatography and nanoelectrospray ionization-quadrupole time-of-flight hybrid mass spectrometer for the detection of milk allergens. J. Agric. Food Chem. 54:1604-1610.

Yao, M., Y. Luo, J. Shi, Y. Zhou, Q. Xu, and Z. Li. 2014. Effects of fermentation by Lactobacillus rhamnosus GG on the antigenicity and allergenicity of four cows' milk proteins. Food Agric. Immunol. 25:545-555.

Yu, L. J., M. Ngadi, and V. Raghavan. 2012. Proteolysis of cheese slurry made from pulsed electric field-treated milk. Food Bioproc. Techol. 5:47-54.

\section{APPENDIX}

Table A1. Supporting information provided by kit manufacturers

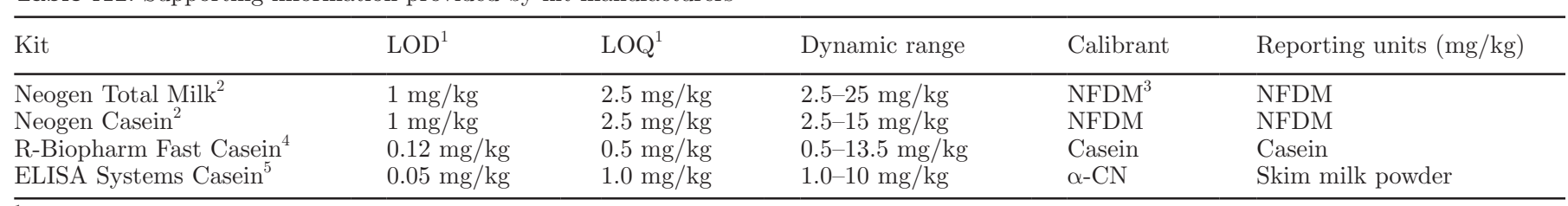

${ }^{1} \mathrm{LOD}=$ limit of detection; $\mathrm{LOQ}=$ limit of quantitation.

${ }^{2}$ Neogen Corporation, Lansing, MI.

${ }^{3} \mathrm{NFDM}=$ nonfat dry milk.

${ }^{4}$ R-Biopharm AG, Darmstadt, Germany.

${ }^{5}$ ELISA Systems, Queensland, Australia. 